RESEARCH ARTICLE

\title{
Validation of Inductive cum Targeted Yield Model based Fertiliser Prescription Equations for Pearl millet (var. CO 10) on Inceptisol
}

Kanchana. $B^{1}$, Santhi. $R^{* 1}$, Maragatham. $S^{1}$ and Chandrasekhar., $C . N^{2}$

*1Department of Soil Science and Agricultural Chemistry, Directorate of Natural Resource Management, Tamil Nadu Agricultural University, Coimbatore-3. 2Department of Crop Physiology,Tamil Nadu Agricultural University, Coimbatore - 641003.

Received : $20^{\text {th }}$ May, 2020

Revised : $03^{\text {rd }}$ June, 2020

Accepted : $17^{\text {th }}$ June, 2020

\begin{abstract}
The present investigation was undertaken to validate the Inductive cum Targeted yield model based Fertiliser Prescription Equations (FPEs) developed under Soil Test Crop Response based Integrated Plant Nutrition System (STCR-IPNS) for desired yield target of pearl millet (var CO 10) on a mixed black calcareous soil (Periyanaickenpalayam soil series - Vertic Ustropept). The field experiment was conducted during Kharif 2019 at TNAU Farm, Coimbatore, and was laid out in a randomized block design with ten treatments that were replicated thrice. The results emanated from the field experiment brought forth the fact that the various growth and yield attributes of pearl millet were significantly influenced by STCR treatments as compared to blanket treatments. There was a $\pm 10 \%$ variation in achievement of yield targets proving the validity of the fertiliser prescription equations developed for desired yield target of pearl millet (var CO 10) on a mixed black calcareous soil. Using the data on grain yield and quantity of nutrients applied, the various parameters viz., per cent achievement, response ratio and benefit: cost ratio were computed. Among the treatments, STCR-IPNS-3.5 t ha-1 has demonstrated its supremacy by registering higher grain yield of 3455 $\mathrm{kg} \mathrm{ha}^{-1}$ with a relatively higher response ratio of $12.57 \mathrm{~kg} \mathrm{~kg}^{-1}$ and BCR of 1.94. STCR - IPNS-3.5 t ha-1 has recorded a yield increase of 43.1, 21.2 and 74.6 per cent over blanket (100\% RDF), blanket plus FYM 12.5 t ha-1,and farmer's practice respectively and the increase in response ratio was 4.28 , 1.18 and $5.27 \mathrm{~kg} \mathrm{~kg}^{-1}$ respectively. Therefore, for achieving higher grain yield, nutrient uptake, response ratio, and BCR in pearl millet (var CO 10) on a mixed black calcareous soil (Periyanaickenpalayam soil series - Vertic Ustropept), STCR-IPNS based fertiliser prescriptions can be followed.
\end{abstract}

Keywords: Mixed black calcareous soil, Pearl millet, Targeted yield model, Fertilizer prescription equations, STCR-IPNS.

\section{INTRODUCTION}

General or blanket fertiliser recommendations are not based on soil fertility and may lead either to under or over usage of fertilisers. Therefore, an appropriate approach could be the recommendations emanating from Soil Test Crop Response Correlation (STCR) studies, which is based on the Inductive cum Targeted yield concept (Ramamoorthy et al., 1967). Hence, Soil Test Crop Response based Integrated Plant Nutrition System (STCR-IPNS) can help in meeting the goal of balanced fertilisation through the conjunctive use of inorganic fertilizers along with organic manures like FYM which is applied at different dosages with different yield targets (Jaga and Upadhyay, 2013). STCR-IPNS studies were undertaken in different parts of India (Dey and Bhogal, 2016), and Tamil Nadu and fertiliser prescriptions have been derived and validated for desired yield target of major field and horticultural crops on different soil types. These prescriptions are of practical importance for efficient and judicious use of fertilisers in increasing crop production, and in addition, prescriptions for desired yield target of crops could be made based on the resource availability of farmers (Dey and Santhi, 2014). The equations are to be validated before they are recommended for adoption by various stakeholders.

Pearl millet (Pennisetum glauccum), an important coarse cereal crop grown mostly in the arid and semi-arid tropical regions and India had witnessed a significant breakthrough in total production and productivity of pearl millet after the release of high yielding varieties (Yadav, 2016). In Tamil Nadu, pearl millet is cultivated on an area of 0.080 lakh 
hectare with the production of 0.182 lakh tones and productivity of $2275 \mathrm{~kg} \mathrm{ha}^{-1}$ (Indiastat, 2019). Though, it is considered as a poor man's crop, it performs as an excellent crop in a short growing season under improved crop management practices. General or blanket recommendation of 70:35:35 $\mathrm{kg} \mathrm{N}, \mathrm{P}_{2} \mathrm{O}_{5}$, and $\mathrm{K}_{2} \mathrm{O}$ ha-1 respectively, along with FYM @ 12.5 t ha-1,is being followed for pearl millet for different varieties in Tamil Nadu. Therefore the present investigation has been undertaken to elucidate the effect of varying fertiliser $\mathrm{N}, \mathrm{P}$ and $\mathrm{K}$ doses and FYM as IPNS strategy on growth and yield attributes, yield and N, P and K uptake and to validate the Fertiliser Prescription Equations developed under STCR-IPNS for Pearl millet (var C010) on mixed black calcareous soil (Periyanaickenpalayam series- Vertic Ustropept).

\section{MATERIAL AND METHODS}

The experiment was conducted at field No. 74, Eastern Block Farm, Tamil Nadu Agricultural University, Coimbatore during Kharif season of 2019. The soil is sandy clay loam in texture, mixed black calcareous representing Periyanaickenpalayam series (Vertic Ustropept). The experiment was laid out in Randomized Block design with ten treatments and three replications. Three different levels of yield targets were fixed based on the yield range of Pearl millet (var. CO 10). The treatments are : $\mathrm{T}_{1}$ - STCR - NPK alone $2.5 \mathrm{t} \mathrm{ha}^{-1}, \mathrm{~T}_{2}$ - STCR - NPK alone $3.0 \mathrm{t} \mathrm{ha}^{-1}, \mathrm{~T}_{3}$ - STCR - NPK alone $3.5 \mathrm{t} \mathrm{ha}^{-1}$, $\mathrm{T}_{4}$ - STCR - IPNS $2.5 \mathrm{t}^{-1}$, $\mathrm{T}_{5}$ - STCR -IPNS $3.0 \mathrm{t}$ ha-1 $^{-1}, \mathrm{~T}_{6}$ - STCR - IPNS-3.5 t ha-1, $\mathrm{T}_{7}$ - Blanket (100\% RDF ), T8 - Blanket + FYM @ 6.25 t ha-1 $^{-1}$, T9 - Farmer's practice and $\mathrm{T}_{10}$ - Absolute control. The initial soil sample was low in available nitrogen and high in available phosphorus and potassium, medium in organic carbon, sufficient in available $\mathrm{Cu}$ and $\mathrm{Mn}$, while deficient in available Fe and $\mathrm{Zn}$.

The fertiliser doses for various yield targets were calculated using the Fertiliser Prescription equations as furnished below and for STCR - IPNS treatments, the contribution of N,P and $\mathrm{K}$ nutrients from FYM in terms of fertiliser $\mathrm{N}, \mathrm{P}_{2} \mathrm{O}_{5}$ and $\mathrm{K}_{2} \mathrm{O}$ was reduced from inorganic fertilizers, and the dosage was calculated.

\begin{tabular}{lllr}
\multicolumn{3}{c}{ STCR-NPK alone } & STCR-IPNS (NPK + FYM ) \\
$\mathrm{FN}$ & $=6.17 \mathrm{~T}-0.58 \mathrm{SN} \quad \mathrm{FN}=$ & $6.17 \mathrm{~T}-0.58 \mathrm{SN}-0.61 \mathrm{ON}$ \\
$\mathrm{FP}_{2} \mathrm{O}_{5}=$ & $3.02 \mathrm{~T}-2.00 \mathrm{SP} \quad \mathrm{FP}_{2} \mathrm{O}_{5}=3.02 \mathrm{~T}-2.00 \mathrm{SP}-0.83 \mathrm{OP}$ \\
$\mathrm{FK}_{2} \mathrm{O}^{\prime}$ & $2.89 \mathrm{~T}-0.14 \mathrm{SK} \quad \mathrm{FP}_{2} \mathrm{O}_{5}=2.89 \mathrm{~T}-0.14 \mathrm{SK}-0.56 \mathrm{OK}$
\end{tabular}

where, $\mathrm{FN}, \mathrm{FP}_{2} \mathrm{O}_{5}$, and $\mathrm{FK}_{2} \mathrm{O}$ are fertiliser $\mathrm{N}, \mathrm{P}_{2} \mathrm{O}_{5}$ and $\mathrm{K}_{2} \mathrm{O}$ in $\mathrm{kg}^{-1}$, respectively; $\mathrm{T}$ is the grain yield target in q ha-1; SN, SP and SK are available N, P and $\mathrm{K}$ in $\mathrm{kg}^{-1}$, respectively and ON, OP and OK are the quantities of $\mathrm{N}, \mathrm{P}$ and $\mathrm{K}$ in $\mathrm{kg}^{-1} \mathrm{~h}^{-1}$ supplied through FYM respectively.

The initial soil sample was analysed for available N (Subbiah and Asija, 1956), available P (Olsen et al., 1954), available K (Stanford and English, 1949) and available micronutrients (Lindsay and Norvell, 1978) as per standard protocols. The crop was grown to maturity by following the package of practices as per the Crop Production Guide of TNAU. The growth attributes viz., plant height, no. of tillers per hill, leaf area, leaf area index, SPAD chlorophyll content and yield attributes viz., earhead length, girth, weight of earhead, weight of grains per ear head and thousand grain weight were recorded. The crop was harvested at maturity, and plot-wise grain and straw yields were recorded. Likewise, plant and grain samples were collected, processed, and analyzed for their total $\mathrm{N}$ (Humphries, 1956), P and K contents (Piper,1966), and their total N, P and $\mathrm{K}$ uptake was computed. The experimental data was applied to statistical analysis with a scope to enlighten the performance of varying fertiliser doses of $\mathrm{N}, \mathrm{P}$, and $\mathrm{K}$ and IPNS on growth attributes, yield and $\mathrm{N}, \mathrm{P}$, and $\mathrm{K}$ uptake. Based on the data recorded from the validation experiment, the following parameters were computed

$$
\begin{aligned}
& \text { Percent Yield obtained in STCR treatment( } \mathrm{t} \mathrm{ha}^{-1} \text { ) } \\
& \text { achievement }=\frac{\text { Yield targeted }\left(\mathrm{t} \mathrm{ha}^{-1}\right)}{\mathrm{P}} \times 100 \\
& \text { Response Ratio }=\quad \text { Response }\left(\mathrm{kg} \mathrm{ha}^{-1}\right) \\
& \left(\mathrm{RR}-\mathrm{kg} / \mathrm{kg}^{-1}\right)=\quad \text { Quantities of fertiliser } \mathrm{N}, \mathrm{P}_{2} \mathrm{O}_{5} \text { and } \\
& \mathrm{K}_{2} \mathrm{O} \text { applied }\left(\mathrm{kg} \mathrm{ha}^{-1}\right) \\
& \mathrm{BCR}\left(\text { Gittinger,1982) }=\frac{\text { Gross returns }\left(\mathrm{Rs}_{\mathrm{h}} \mathrm{ha}^{-1}\right)}{\text { Total cost of cultivation(Rs.ha } \left.{ }^{-1}\right)}\right.
\end{aligned}
$$

\section{RESULTS AND DISCUSSION}

\section{Growth attributes}

A perusal of the data on growth attributes (Table 1) clearly revealed that STCR - IPNS - $3.5 \mathrm{t} \mathrm{ha}^{-1}$ has recorded the highest plant height $(221.3 \mathrm{~cm})$, no. of tillers per hill (4.5), leaf area per plant (2631.2 $\mathrm{cm}^{2}$ ), leaf area index (3.898) and SPAD chlorophyll content (43.9) which was comparable with STCRNPK alone - $3.5 \mathrm{t} \mathrm{ha}^{-1}$ and significantly superior over all other treatments. In general, STCR-IPNS treatments for various yield targets recorded growth attributes on par with their respective STCR-NPK alone treatments, while blanket treatments, farmer's practice, and control had recorded relatively lower attributes as compared to STCR treatments (except $\mathrm{T}_{1}$ ). The favourable influence of STCR-IPNS might be due to better utilization of nutrients by plants which led to increased plant height, no.of tillers per hill, synthesis of more photosynthates and finally resulted in increased leaf area which stimulated the cell division resulting in overall better vegetative growth and higher leaf area index. Also, ready access and higher uptake of nutrients enhanced the development of new tissues, which resulted in higher chlorophyll content.The findings were corroborated with Aziz et al. (2010), Dapake (2014), Bamboriya

$107|4-6| 2$ 
et al. (2017), Neha et al. (2017) and Senthilkumar et al. (2018) respectively for leaf area, no. of tillers per hill, SPAD chlorophyll content, leaf area index and plant height.

\section{Yield attributes}

The yield attributes viz., length, girth, and weight of ear head, weight of grains per ear head and thousand grain weight were responsible for grain production of pearl millet.

Table 1.Effect of varying fertiliser doses of NPK and IPNS on growth attributes at harvest stage of pearl millet (var. CO 10)

\begin{tabular}{|c|c|c|c|c|c|c|}
\hline Treat & nents & \multirow{2}{*}{$\begin{array}{r}\begin{array}{r}\text { Plant } \\
\text { height } \\
(\mathrm{cm})\end{array} \\
186.4\end{array}$} & \multirow{2}{*}{$\begin{array}{r}\begin{array}{l}\text { Number of } \\
\text { tillers hill }^{-1}\end{array} \\
3.4\end{array}$} & \multirow{2}{*}{$\begin{array}{r}\begin{array}{r}\text { Leaf area } \\
\text { per plant } \\
\left(\mathrm{cm}^{2}\right)\end{array} \\
1982.5\end{array}$} & \multirow{2}{*}{$\begin{array}{r}\begin{array}{r}\text { Leaf Area } \\
\text { Index }\end{array} \\
2.94\end{array}$} & \multirow{2}{*}{$\begin{array}{r}\begin{array}{r}\text { SPAD } \\
\text { Chlorophyll } \\
\text { content }\end{array} \\
31.9\end{array}$} \\
\hline T1 & STCR- NPK alone $-2.5 \mathrm{t} \mathrm{ha}^{-1}$ & & & & & \\
\hline $\mathrm{T} 2$ & STCR- NPK alone $-3.0 \mathrm{t} \mathrm{ha}^{-1}$ & 202.6 & 4.0 & 2236.9 & 3.31 & 37.6 \\
\hline T3 & STCR - NPK alone - $3.5 \mathrm{t} \mathrm{ha}^{-1}$ & 217.8 & 4.3 & 2571.8 & 3.81 & 41.5 \\
\hline T4 & STCR - IPNS - 2.5 t ha-1 & 193.5 & 3.7 & 2028.4 & 3.01 & 33.2 \\
\hline T5 & STCR - IPNS - 3.0 t ha-1 $^{-1}$ & 209.2 & 4.1 & 2311.2 & 3.42 & 39.8 \\
\hline T6 & STCR - IPNS - $3.5 \mathrm{t} \mathrm{ha}^{-1}$ & 221.3 & 4.5 & 2631.2 & 3.90 & 43.9 \\
\hline T7 & Blanket 100\% RDF & 184.0 & 3.3 & 1827.6 & 2.71 & 29.8 \\
\hline T8 & Blanket + FYM @ 12.5 t ha-1 & 197.1 & 3.8 & 2175.1 & 3.22 & 36.8 \\
\hline T9 & Farmer's Practice & 182.9 & 3.1 & 1785.4 & 2.65 & 27.3 \\
\hline \multirow[t]{3}{*}{ T10 } & Absolute control & 132.6 & 2.8 & 1546.4 & 2.29 & 26.1 \\
\hline & SEd & 3.9 & 0.16 & 63.5 & 0.066 & 2.7 \\
\hline & $\mathrm{CD}(\mathrm{P}=0.05)$ & 8.1 & 0.3 & 133.5 & 0.14 & 5.7 \\
\hline
\end{tabular}

Accordingly, in the present investigation, the earhead length $(27.50 \mathrm{~cm})$, girth $(3.66 \mathrm{~cm})$, weight (48.33 g), weight of grains per ear head (29.13 g) and thousand grain weight (15.05 g) recorded were proportionate with STCR - NPK alone - 3.5 t ha-1 $^{-1}$ having the values of $26.99 \mathrm{~cm}, 3.55 \mathrm{~cm}, 45.75 \mathrm{~g}$,
$28.03 \mathrm{~g}$, and $14.52 \mathrm{~g}$, respectively. Similar to growth attributes, the trend of results clearly showed that STCR treatments (except $\mathrm{T}_{4}$ and $\mathrm{T}_{1}$ with $\mathrm{T}_{8}$ ) recorded significantly higher yield attributes as compared to blanket treatments, farmer's practice, and absolute control (Table 2).

Table 2.Effect of varying fertiliser doses of NPK and IPNS on yield attributes of pearl millet (var. CO 10)

\begin{tabular}{|c|c|c|c|c|c|c|}
\hline \multicolumn{2}{|c|}{ Treatments } & \multirow{2}{*}{$\begin{array}{r}\begin{array}{r}\text { Ear head } \\
\text { length } \\
(\mathrm{cm})\end{array} \\
21.9\end{array}$} & \multirow{2}{*}{ 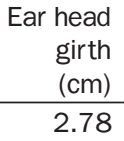 } & \multirow{2}{*}{$\begin{array}{r}\begin{array}{r}\text { Weight of } \\
\text { ear head } \\
(\mathrm{g})\end{array} \\
31.4\end{array}$} & \multirow{2}{*}{$\begin{array}{r}\begin{array}{r}\text { Weight } \\
\text { of grains / } \\
\text { ear head }(\mathrm{g})\end{array} \\
21.9\end{array}$} & \multirow{2}{*}{$\begin{array}{r}\text { Test weight } \\
\text { (1000 grain } \\
\text { weight) }(\mathrm{g}) \\
11.9\end{array}$} \\
\hline T1 & STCR- NPK alone $-2.5 \mathrm{t} \mathrm{ha}^{-1}$ & & & & & \\
\hline T2 & STCR- NPK alone $-3.0 \mathrm{t} \mathrm{ha}^{-1}$ & 24.8 & 3.22 & 39.2 & 24.4 & 13.4 \\
\hline T3 & STCR - NPK alone - 3.5t ha-1 & 27.0 & 3.55 & 45.8 & 28.0 & 14.5 \\
\hline T4 & STCR - IPNS - 2.5 t ha-1 $^{-1}$ & 22.2 & 2.89 & 32.6 & 22.1 & 12.1 \\
\hline T5 & STCR - IPNS - 3.0 t ha-1 $^{-1}$ & 25.3 & 3.31 & 40.3 & 25.9 & 14.0 \\
\hline T6 & STCR - IPNS - 3.5 t ha-1 & 27.5 & 3.66 & 48.3 & 29.1 & 15.1 \\
\hline T7 & Blanket 100\% RDF & 20.1 & 2.56 & 29.7 & 20.7 & 11.3 \\
\hline T8 & Blanket + FYM @ 12.5 t ha ${ }^{-1}$ & 24.4 & 3.15 & 38.4 & 24.2 & 13.1 \\
\hline T9 & Farmer's Practice & 19.7 & 2.41 & 28.0 & 19.0 & 11.0 \\
\hline \multirow[t]{3}{*}{ T10 } & Absolute control & 17.2 & 2.12 & 20.2 & 11.5 & 10.1 \\
\hline & SEd & 0.91 & 0.06 & 1.33 & 1.16 & 0.64 \\
\hline & $\mathrm{CD}(\mathrm{P}=0.05)$ & 1.90 & 0.12 & 2.79 & 2.43 & 1.35 \\
\hline
\end{tabular}

Among the STCR treatments, STCR-IPNS treatments registered numerically higher values for various yield attributes than their respective STCR - NPK alone. The favourable influence of STCR - IPNS treatments might be due to the improvement in soil physical, chemical, and biological properties, balanced availability of nutrients, leading to better filling of grains and bold sized seeds, thus enhancing the overall performance of crop growth and increased yield attributes. The findings of the present investigation were also reported by Neha et al. (2017), Senthilkumar et al. (2018), and Singh et al.(2020).

\section{Grain and straw yield}

The data on grain yield of pearl millet in Table 3 showed that the highest grain yield of $3455 \mathrm{~kg} \mathrm{ha}^{-1}$ was recorded with STCR - IPNS - $3.5 \mathrm{t} \mathrm{ha}^{-1}$ which was on par with STCR-NPK alone-3.5 t ha-1 $(3344 \mathrm{~kg}$

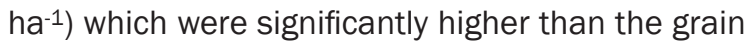
yield recorded by all other treatments. Among the STCR treatments, all the STCR-IPNS treatments were comparable with their corresponding STCR - NPK alone treatments. Yield targeting @ 3.5 and $3.0 \mathrm{t}$ ha-1 $^{-1}$ of grain yield significantly surpassed the yield recorded by blanket plus FYM @ 12.5 t ha-1 (2850 
$\left.\mathrm{kg} \mathrm{ha}^{-1}\right)$. Though low yield targeting of $2.5 \mathrm{t} \mathrm{ha}^{-1}$ of grain yield recorded comparable with blanket (100\% RDF alone), it was significantly higher than farmer's practice (1985 kg ha-1) and absolute control (1255 $\left.\mathrm{kg} \mathrm{ha}^{-1}\right)$. The percentage increase in yield due to STCR - IPNS 3.5 t ha-1 over blanket (100\% RDF), blanket plus FYM 12.5 t ha-1,and farmer's practice was 43.1, 21.2, 43.1 and 74.6 per cent respectively. STCR- IPNS 3.5 t ha $^{-1}$ recorded the highest straw yield of $7497 \mathrm{~kg} \mathrm{ha}^{-1}$,which was on par with straw yield of STCR - NPK alone $3.5 \mathrm{t} \mathrm{ha}^{-1}$ (7256 kg ha-1). Similar trend of results as observed in grain yield was noticed in straw yield also.

Table 3. Results of validation experiment on Pearl millet (var. CO 10)

\begin{tabular}{|c|c|c|c|c|c|c|c|c|c|c|c|}
\hline \multicolumn{2}{|c|}{ Treatments } & \multicolumn{3}{|c|}{ Fertiliser doses (kg ha-1) } & \multirow{3}{*}{$\begin{array}{r}\mathrm{FK}_{2} \mathrm{O} \\
18^{*}\end{array}$} & \multirow{3}{*}{$\begin{array}{r}\begin{array}{c}\text { Grain } \\
\text { Yield } \\
\left(\mathrm{kg} \mathrm{ha}^{-1}\right)\end{array} \\
2495\end{array}$} & \multirow{2}{*}{$\begin{array}{l}\text { Straw yield } \\
\left(\mathrm{kg} \mathrm{ha}^{-1}\right)\end{array}$} & \multirow{2}{*}{\multicolumn{2}{|c|}{$\begin{array}{l}\text { Per cent } \\
\text { achieve- } \\
\text { ment }\end{array}$}} & \multirow{2}{*}{$\begin{array}{c}\text { Response } \\
\text { Ratio (RR) } \\
\left(\mathrm{kg} \mathrm{kg}^{-1}\right)\end{array}$} & \multirow{2}{*}{$\begin{array}{l}\text { Benefit: } \\
\text { Cost ratio } \\
\text { (BCR) }\end{array}$} \\
\hline & & \multirow{2}{*}{$\begin{array}{c}\begin{array}{c}\text { FYM } \\
\left(\mathrm{t} \mathrm{ha}^{-1}\right)\end{array} \\
\end{array}$} & \multirow{2}{*}{$\begin{array}{l}\text { FN } \\
59\end{array}$} & \multirow{2}{*}{$\begin{array}{r}\mathrm{FP}_{2} \mathrm{O}_{5} \\
18^{*}\end{array}$} & & & & & & & \\
\hline T1 & STCR-NPK alone-2.5 t ha-1 & & & & & & & 304 & 99.8 & 13.05 & 1.44 \\
\hline $\mathrm{T} 2$ & STCR-NPK alone-3.0 t ha-1 & - & 90 & 27 & $18 *$ & 2901 & & 237 & 96.7 & 12.75 & 1.69 \\
\hline T3 & STCR-NPK alone-3.5 t ha-1 & - & 121 & 42 & $18 *$ & 3344 & & 256 & 95.5 & 11.94 & 1.91 \\
\hline $\mathrm{T} 4$ & STCR-IPNS-2.5 t ha ${ }^{-1}$ & 12.5 & $35 *$ & $18 *$ & $18 *$ & 2540 & & 560 & 101.6 & 13.53 & 1.46 \\
\hline T5 & STCR-IPNS-3.0 t ha-1 & 12.5 & 50 & $18^{*}$ & $18 *$ & 2991 & & 431 & 99.7 & 13.46 & 1.70 \\
\hline T6 & STCR-IPNS-3.5 t ha ${ }^{-1}$ & 12.5 & 81 & 20 & $18 *$ & 3455 & & 497 & 98.7 & 12.57 & 1.94 \\
\hline T7 & Blanket (100 \% RDF) & - & 70 & 35 & 35 & 2415 & & 171 & - & 8.29 & 1.37 \\
\hline T8 & Blanket + FYM @ 12.5 t ha-1 & 12.5 & 70 & 35 & 35 & 2850 & & 124 & - & 11.39 & 1.56 \\
\hline T9 & Farmer's Practice & - & 60 & 20 & 20 & 1985 & & 947 & - & 7.30 & 0.94 \\
\hline \multirow[t]{3}{*}{ T10 } & Absolute control & - & 0 & 0 & 0 & 1255 & & 810 & - & & 0.78 \\
\hline & & & \multicolumn{2}{|r|}{ SEd } & & 152 & \multicolumn{2}{|c|}{331} & & & \\
\hline & & & \multicolumn{2}{|r|}{$C D(p=0.05)$} & & 319 & \multicolumn{2}{|c|}{696} & & & \\
\hline \multicolumn{12}{|c|}{ * maintenance dose; STCR-IPNS: NPK+ FYM@12.5t ha-1 } \\
\hline & & & & \multicolumn{8}{|c|}{ Initial Soil Test Values } \\
\hline \multicolumn{4}{|c|}{ Fertiliser Prescription equations } & \multicolumn{6}{|c|}{ Major Nutrients (kg ha $\left.{ }^{-1}\right)$} & \multicolumn{2}{|c|}{ Micronutrients ( $\mathrm{mg} \mathrm{kg}^{-1}$ ) } \\
\hline FN & $=6.17 \mathrm{~T}-0.58 \mathrm{SN}-0.61 \mathrm{ON}$ & & & $\begin{array}{l}\mathrm{KMnO} 4 \\
:\end{array}$ & & : & 164 & DTPA-Zn & $:$ & : & 0.90 \\
\hline $\mathrm{FP}_{2} \mathrm{O}_{5}$ & $=3.02 \mathrm{~T}-2.00 \mathrm{SP}-0.83 \mathrm{OP}$ & & & $\begin{array}{l}\text { Olsen-F } \\
:\end{array}$ & & : & 32.0 & DTPA-Fe & $:$ & : & 3.32 \\
\hline \multirow[t]{2}{*}{$\mathrm{FK}_{2} \mathrm{O}=$} & $=2.89 \mathrm{~T}-0.14 \mathrm{SK}-0.56 \mathrm{OK}$ & & & $\mathrm{NH} 4 \mathrm{OA}$ & c-K: & : & 520 & DTPA-Mn & : & : & 6.45 \\
\hline & & & & & & & & DTPA-Cu & : & $:$ & 1.44 \\
\hline
\end{tabular}

The enhancement in both grain and straw yield of STCR - IPNS 3.5 t ha-1 $^{-1}$ is due to the balanced supply of nutrients through the combined application of inorganic fertilizers along with organic manure viz., FYM. It deliberately emphasizes that crop meets the immediate nutrient requirement through inorganic fertilisers and the nutrient requirement for later growth stages has been met by organic manures which had significant effect not only in improving the yield but also in reducing the nutrient losses to the environment thus managing the optimum nutrient supply (Manik et al., 2019). Similar results were reported by Suresh and Santhi (2018) in maize and Ravikiran et al. (2018) in pearl millet on black calcareous soils.

\section{Per cent achievement}

Achievement of aimed yield targets is one of the important parameters to be recorded for the validation of fertiliser prescription equations developed for a particular crop on a specific soil type. According to Velayudham et al. (1985), if the targeted yield was achieved within \pm 10 per cent variation, then the fertiliser prescription equations are valid enough to prescribe doses. The present validation experiment results on pearl millet clearly illustrated that per cent achievement was within \pm 10 per cent (90-110\%) variation at all yield target levels proving the validity of the fertiliser prescription equations for pearl millet on Inceptisol (Table 3). The highest per cent achievement was recorded with yield targets of STCR - IPNS 2.5 t ha-1 ${ }^{-1}(101.6$ \%) followed by STCR - NPK alone $2.5 \mathrm{t} \mathrm{ha}^{-1}(99.8 \%)$, STCR - IPNS 3.0 t ha-1 $^{-1}(99.7 \%)$ and STCR - IPNS 3.5 $\mathrm{t} \mathrm{ha}^{-1}$ ( $\left.98.7 \%\right)$. It was distinct that achievement of targets was the highest with lowest yield targets (2.5 $\mathrm{t} \mathrm{ha}^{-1}$ and $3.0 \mathrm{t} \mathrm{ha}^{-1}$ ) than the highest yield target ( $3.5 \mathrm{t} \mathrm{ha}^{-1}$ ) under both NPK alone and IPNS. The results were in agreement with the findings of Suresh and Santhi (2018) in maize and Kirankumar et al. (2018) in brinjal.

\section{Response ratio and Benefit:cost ratio}

Among the STCR treatments, STCR - IPNS treatments recorded relatively higher response ratio (fertiliser use efficiency) than their corresponding NPK alone treatments (Table 3). The response ratio of pearl millet varied from $7.30 \mathrm{~kg} \mathrm{~kg}^{-1}$ in farmer's practice to $13.53 \mathrm{~kg} \mathrm{~kg}^{-1}$ in STCR - IPNS - $2.5 \mathrm{t} \mathrm{ha}^{-1}$. The higher response ratio (13.53 
$\mathrm{kg} \mathrm{kg}^{-1}$ ) was observed in $\mathrm{T}_{4}$ (STCR - IPNS - 2.5 $\mathrm{t} \mathrm{ha}^{-1}$ ) compared to all the other treatments and the least value of response ratio was recorded in $\mathrm{T}_{9}$ (Farmer's practice) (7.30 kg kg-1). Followed by $\mathrm{T}_{4}$ (STCR - IPNS - $2.5 \mathrm{t} \mathrm{ha}^{-1}$ ), the higher response ratio (13.46 kg kg-1) was achieved by $T_{5}$ (STCR - IPNS 3.0 t ha-1 $^{-1}$ ). The response ratio recorded by blanket

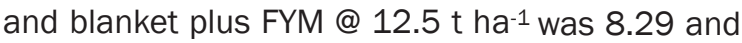

$11.39 \mathrm{~kg} \mathrm{~kg}^{-1}$,respectively, which was relatively lower compared to STCR-NPK alone and STCR-IPNS treatments with yield targets of 2.5,3.0,3.5 t ha-1. The increase in response ratio due to STCR- IPNS $3.5 \mathrm{t} \mathrm{ha}^{-1}$ over blanket recommendation was 4.28 kg kg-1, blanket plus FYM @ 12.5 t ha-1 was 1.18 kg $\mathrm{kg}^{-1}$ and farmer's practice was $5.27 \mathrm{~kg} \mathrm{~kg}^{-1}$.

Table 4. Effect of varying fertiliser doses of NPK and IPNS on total N, P and K uptake by pearlmillet(var. C010) at harvest stage

\begin{tabular}{|c|c|c|c|c|}
\hline \multicolumn{2}{|r|}{ Treatments } & Nitrogen $\left(\mathrm{kg} \mathrm{ha}^{-1}\right)$ & Phosphorus (kg ha $\left.{ }^{-1}\right)$ & Potassium (kg ha-1) \\
\hline$T_{1}$ & STCR- NPK alone $-2.5 \mathrm{t} \mathrm{ha}^{-1}$ & 64.65 & 17.05 & 55.78 \\
\hline $\mathrm{T}_{2}$ & STCR- NPK alone $-3.0 \mathrm{t} \mathrm{ha}^{-1}$ & 80.76 & 21.80 & 65.94 \\
\hline $\mathrm{T}_{3}$ & STCR - NPK alone - 3.5t ha-1 & 99.44 & 26.66 & 76.98 \\
\hline $\mathrm{T}_{4}$ & STCR - IPNS - 2.5 t ha-1 & 68.58 & 18.49 & 58.42 \\
\hline$T_{5}$ & STCR - IPNS - 3.0 t ha-1 & 85.75 & 22.78 & 68.09 \\
\hline $\mathrm{T}_{6}$ & STCR - IPNS - 3.5 t ha-1 & 104.93 & 28.64 & 79.72 \\
\hline $\mathrm{T}_{7}$ & Blanket 100\% RDF & 62.80 & 16.35 & 54.23 \\
\hline $\mathrm{T}_{8}$ & Blanket + FYM @ 12.5 t ha-1 & 78.14 & 20.80 & 64.60 \\
\hline$T_{9}$ & Farmer's Practice & 53.62 & 14.26 & 51.20 \\
\hline $\mathrm{T}_{10}$ & Absolute control & 31.53 & 8.04 & 29.28 \\
\hline & $\begin{array}{c}\text { SEd } \\
C D(p=0.05)\end{array}$ & $\begin{array}{l}2.74 \\
5.76\end{array}$ & $\begin{array}{l}1.53 \\
3.21\end{array}$ & $\begin{array}{l}1.89 \\
3.96\end{array}$ \\
\hline
\end{tabular}

The highest value of BCR was secured in STCRIPNS 3.5 t ha-1 $^{-1}(1.94)$ than the STCR- NPK alone -3.5 t ha-1 (1.91). The BCR of blanket (100\% RDF) and farmer's practice was 1.37 and 0.94 , respectively, which was lower than STCR treatments and blanket plus FYM @ 12.5 t ha-1 $^{-1}$ (1.56). The increase in BCR due to STCR - IPNS 3.5 t ha-1 $^{-1}$ over blanket (100\% RDF), blanket plus FYM @ 12.5 t ha-1 and farmer's practice was $0.57,0.38$ and 1.00 , respectively. The higher net returns was mainly due to high productivity and combined application of organic manures along with inorganic fertilisers which led to profitable income. The supremacy of STCR- IPNS over farmer's practice exhibited an identical trend as reported by Sharma et al. (2015) for pearl millet and Udayakumar et al. (2019) in pearl millet hybrid on Inceptisol.

\section{Nutrient Uptake by pearl millet}

The highest total $\mathrm{N}, \mathrm{P}$ and $\mathrm{K}$ uptake was

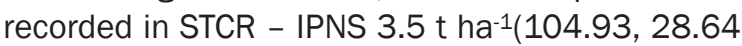
and $79.72 \mathrm{~kg} \mathrm{ha}^{-1}$ ), which was relatively higher than all other treatments except STCR - NPK alone 3.5 t ha- ${ }^{-1}\left(99.44,26.66\right.$, and $\left.76.98 \mathrm{~kg} \mathrm{ha}^{-1}\right)$ (Table 4). The results clearly figured out the fact that STCR treatments (except $\mathrm{T}_{1}$ ) excelled significantly in increasing the N,P and $\mathrm{K}$ uptake than blanket (100\% RDF) $\left(62.8,16.35\right.$ and $\left.54.23 \mathrm{~kg} \mathrm{ha}^{-1}\right)$ and farmer's practice $\left(53.62,14.26\right.$ and $\left.51.20 \mathrm{~kg} \mathrm{ha}^{-1}\right)$. It proved that with an increase in yield targets, there was a respective rise in total $\mathrm{N}, \mathrm{P}$ and $\mathrm{K}$ uptake. All the STCR treatments recorded significantly higher total $\mathrm{N}, \mathrm{P}$, and $\mathrm{K}$ uptake , which might be due to higher nutrient content and respective grain and straw yield.
The lowest total N, P, and K uptake (31.53, 8.04, and $29.28 \mathrm{~kg} \mathrm{ha}^{-1}$ ) was reported by $\mathrm{T}_{10}$ (Absolute control) due to lower grain and straw yield and inadequate availability of nutrients. The total nitrogen uptake was 3.66 and 1.32 fold higher than the total phosphorus and potassium uptake recorded in STCR-IPNS-3.5 t ha-1. The increase in N, P and K uptake with IPNS might be due to solubilization of native nutrients, chelation of complex intermediate organic molecules produced during decomposition of added FYM, its mobilization and accumulation of different nutrients in different plant parts.Application of inorganic fertilizers along with organic manures provides sufficient nutrients to the available pool, which contributes adequate amount of nutrients at the right time for the plant growth (Ravikiran et al., 2018). The integrated use of organics and inorganics provides favourable environment for plant growth, root proliferation, and greater multiplication of soil microbes, which resulted in increased total uptake of nutrients (Singh et al.,2020).

\section{CONCLUSION}

It was concluded from the present validation experiment that, the per cent achievement was within $\pm 10 \%$ variation proving the validity of the fertiliser prescription equations for prescribing soil test based fertiliser doses for pearl millet variety. Among the treatments, STCR-IPNS-3.5 t ha- $^{-1}$ has demonstrated its supremacy with significantly higher grain yield (3455 kg ha-1) and a relatively higher response ratio of (12.57 kg kg-1) and BCR of 1.94. STCR - IPNS-3.5 t ha-1 had recorded a yield increase of $43.1,21.2$ and 74.6 per cent over blanket (100\% RDF), blanket plus 
FYM 12.5 t ha-1 $^{-1}$ and farmer's practice respectively and increase in response ratio was 4.28, 1.18 and $5.27 \mathrm{~kg} \mathrm{~kg}^{-1}$ respectively. Therefore, for achieving higher grain yield, nutrient uptake, response ratio and BCR in pearl millet (var CO 10) on a mixed black calcareous soil (Periyanaickenpalayam soil series - Vertic Ustropept), the validated STCR-IPNS based fertiliser prescriptions can be recommended.

\section{REFERENCES}

Aziz,T., Ullah,S., Sattar,A., Nasim,M., Farooq,M. and M.M.Khan. 2010. Nutrient availability and maize (Zea mays) growth in soil amended with organic manures. Int. J. Agric. Biol., 12 (4) :621-624.

Bamboriya, S.D., Bana, R.S., Pooniya, V., Singh,Y.V. and S.Devi. 2017. Effect of planting density and nitrogen management on micronutrient content, soil fertility and microbial properties in conservation agriculture based rainfed pearl millet. IJCS.,5(4) : 849-853.

Dapake,P.P. 2014.Effect of sowing time and nutrient management on growth, yield and quality of Pearl millet cv. Dhanashakti under rainfed condition (Doctoral dissertation, MPKV, University Library, Rahuri).

Dey, P. and H.Bhogal. 2016.Progress Report of the All India Coordinated research Project for Investigation on Soil Test Crop Response Correlation. Indian Institute of Soil Science, Bhopal 224 .

Dey, P. and R. Santhi. 2014. Soil test based fertiliser recommendations for different investment capabilities. In: Tandon, H.L.S. (ed.). Soil Testing for Balanced Fertilisation Technology-Application -Problems-Solutions. p. 49-67.

Gittinger, J. Price. 1982.Economic analysis of agricultural projects. Economic Development Institute of the World Bank.Johns Hopkins University Press. Baltimore, London,Press- p. 505.

Humphries, E.C. 1956. Mineral components and ash analysis.Modern methods of plant analysis. Springer- Verlag, Berlin 1: 468-562.

Jaga, P. K. and V. B. Upadhyay. 2013.Effect of integrated nutrient management on wheat-A review. Innovare J. Agric. Sci., 1.1: 1-3.

Kirankumar Ch, Santhi,R., Maragatham,S., Meena, S. and C.N.Chandrasekhar. 2018. Validation of Soil Test Crop Response based Fertiliser Prescription Equations under Integrated Plant Nutrition System for Hybrid Brinjal on Inceptisol of Andhra Pradesh. Madras Agric. J., 106 (7-9): 517-521.

Lindsay, W.L. and W.A. Norvell. 1978. Development of a DTPA soil test for zinc, iron, manganese and copper. Soil Sci. Soc. Am. J., 42: 421-428.

Manik, S.N., Pengilley, G., Dean, G., Field, B., Shabala, S. and M.Zhou. 2019. Soil and crop management practices to minimize the impact of waterlogging on crop productivity. Frontiers in Plant Science.Science. https://doi.org/10.3389/ $\mathrm{fp} / \mathrm{s} .2019 .00140$.

Neha,G.G., Choudhary,P. and S.Kumari. 2017. Effect of different nitrogen levels and varietal performance on growth and yield of summer pearl millet. Int. J. Curr. Microbiol. App. Sci., 6(6) : 861-869.

Olsen, S.R., Cole, C.V., Watanabe, F.S. and L. Dean. 1954. Estimation of available phosphorus in soils by extraction with sodium bicarbonate. U.S.D.A. Circ. 939.U.S. Govt. Printing Office, Washington, DC.

Piper, C.S. 1966.Soil and plant analysis.Hans Publications, Bombay.

Ramamoorthy, B., Narasimham, R.K. and R.S. Dinesh. 1967. Fertilizer application for specific yield targets of Sonora 64 (wheat). Indian Fmg.,17: 43-45.

Ravikiran, K.B., Santhi, R., Meena, S. and P.Sumathi. 2018. Refinement of Soil test crop responseintegrated plant nutrition system based fertilizer prescriptions for pearl millet variety grown Under Inceptisol. Madras Agric. J., 105(4-6):165-169.

Senthilkumar, N., Poonkodi, P. and N.Prabhu. 2018. Response of pearl millet to integrated use of organics and fertilizers.Journal of Ecobiotechnology., 10: 01-04.

Sharma, V.K., Pandey, R.N. and B.M.Sharma. 2015. Studies on long term impact of STCR based integrated fertilizer use on pearl millet (Pennisetum glaucum)-wheat (Triticumaestivum)cropping system in semi arid condition of India. Journal of environmental biology., 36 (1) : 241.

Singh, B., Kumar, A., Gupta, V., Abrol, V., Singh, A.P., Kumar, J., Singh, M., Dadhich, H. and P.Singh. 2020. Effect of organic and inorganic nutrients on pearl millet (Pennisetum glaucum)-gobhi sarson (Brassica napus var. napus) cropping sequence. Indian Journal of Agricultural Sciences.,90 (2) : 302-306.

Stanford, S. and L. English. 1949. Use of flame photometer in rapid soil tests of $\mathrm{K}$ and $\mathrm{Ca}$.Agron. J., 41: 446.

Stat, India. 2019. Socio economic statistical information about India.

Subbiah, B.V. and G.L. Asija. 1956.A rapid procedure for estimation of available nitrogen in soils. Curr. Sci., 25: 259-260.

Suresh,R. and R.Santhi. 2018. Validation of soil test and yield target based fertiliser prescription model for hybrid maize on Vertisol. Int.J.Curr.Microbiol.App. Sci.,7(9): 2131-2139.

Udayakumar Sekaran, Santhi,R., Dey, P., Meena, S. and S.Maragatham. 2019. Validation of soil test and yield target based fertilizer prescription model developed for pearl millet on Inceptisol. Research on Crops., 20(2): 266-274.

Velayutham, M., Reddy, K.C.K. and G.R. Maruthi Sankar. 1985. All India Co-ordinated Research Project on Soil Test Crop Response correlation and its impact on agricultural production. Fert.News., 30(4): 81-95.

Yadav H.P. 2016.Project Coordinator Review-51 $1^{\text {st }}$ annual group meeting. All India Coordinated Pearl Millet Improvement Project Hisar, India.

$107|4-6| 6$ 